\title{
Comparison of two surgical techniques in large incisional hernias
}

\author{
Geniş insizyonel hernilerde iki cerrahi yöntemin karşılaştırılması
}

Mustafa Sit ${ }^{1}$, Ahmet Serkan İlgün ${ }^{2}$, Affan Çakır ${ }^{1}$, Oğuz Çatal ${ }^{3}$, Rıdvan Çakmaz ${ }^{4}$

\begin{abstract}
Objectives: Incisional hernias occur from incisions of previous abdominal operations. It is an often complication of abdominal interventions. Prevalence of incisional hernias is approximately $2.9 \%$ and $3.6 \%$ in vertical midline incisions and transverse incisions, respectively. Incisional hernias cause morbidity and loss of manpower. The only treatment option is surgery. We aimed to compare surgical methods of incisional hernias and discuss the postoperative data in this retrospective report.
\end{abstract}

Methods: We retrospectively analyzed the data of 54 patients with large incisional hernias operated between 2007 and 2011.

Results: We compared age, chronic diseases (e.g. Chronic obstructive pulmonary disease, diabetes mellitus), which may cause postoperative recurrence, gender, personal factors, such as patients undergoing incisional hernia repair mesh over solid fascia less or over than $5 \mathrm{~cm}$ with the placement of decolation; recurrence, the development of postoperative seroma, receiving postoperative drainage and postoperative length of hospital stay were compared. While the recurrence rate of less than 5 above the decolation; seroma development, no significant difference in length of hospital stay and drain times to get.

Conclusion: In conclusion, we think that recurrence rate should be reduced by dissection of $5 \mathrm{~cm}$ intact fascia and grafting in incisional hernias of anterior abdominal wall. $J$ Clin Exp Invest 2014; 5 (1): 36-39

Key words: incisional hernia, hernia repair, recurrence

\section{ÖZET}

Amaç: İnsizyonel herniler, daha önce yapılmış olan abdominal operasyon kesilerinden oluşan fıtıklardır. Batın cerrahisinde cerrahi girişimlerden sonra karın duvarında sık görülen bir komplikasyondur. Değişik kaynaklarda farklı rakamlar verilse de insizyonel herni görülme sıklığı vertikal midline insizyonlarda \%2,9, transvers insizyonlarda \% 3.6 oranında görülmektedir. Abdominal cerrahi sonrası sık görülen insizyonel herni, önemli oranda morbidite ve iş gücü kaybına neden olur. Tek tedavi seçeneği cerrahidir.

Bu retrospektif çalışmada amaç insizyonel hernilerde uyguladığımız cerrahi yöntemleri ve postoperatif takipteki verileri paylaşmaktır.

Yöntemler: Bu çalışmada 2007-2011 yılları arasında tedavi edilen orta hat geniş insizyonel hernili 54 hastanın verileri retrospektif olarak incelenmiştir.

Bulgular: Çalışmada postoperatif nükse sebep olan diyabet, KOAH gibi kronik hastalıklar, yaş, cinsiyet gibi kişisel faktörler ile birlikte insizyonel herni nedeniyle meshli onarım yapılan hastalarda meshin sağlam faysa üzerinde 5 $\mathrm{cm}$ altında ve $5 \mathrm{~cm}$ üzerinde yapılan dekolasyon sonrası yerleştirilmesi ile nüks, postoperatif seroma gelişimi, postoperatif dren alma ve postoperatif hastanede yatış süreleri karşılaştırıldı. $5 \mathrm{~cm}$ üzerinde yapılan dekolasyonda nüks oranı daha az görülürken; seroma gelişimi, hastanede yatış süresi ve dren alma sürelerinde anlamlı farklıık saptanmadı.

Sonuç: Sonuç olarak karın ön duvarı dev insizyonel hernilerde herni kesesi etrafında $5 \mathrm{~cm}$ üzeri sağlam faysa diseksiyonu yapıp greft uygulamanın nüksü en aza indireceğini düşünmekteyiz.

Anahtar kelimeler: İnsizyonel fıtık, fıtık tamiri, nüks

\footnotetext{
${ }^{1}$ Abant izzet Baysal University Hospital, Department of General Surgery, Bolu, Turkey

${ }^{2}$ Çayeli State Hospital, Department of General Surgery, Rize, Turkey

${ }^{3}$ Akçay State Hospital, Department of General Surgery, Balıkesir, Turkey ${ }^{4}$ Adıyaman State Hospital, Department of General Surgery, Adıyaman, Turkey
}

Correspondence: Mustafa Sit,

Abant İzzet Baysal University, Medical Faculty Department of General Surgery, Bolu, Turkey. Email: drmusta-fasit@yahoo.com.tr 


\section{INTRODUCTION}

Insufficient closure of the fascia, poor wound healing, or chronic and long-term conditions that increase intra-abdominal pressure causes incisional hernias. It has been raised more often after advances in abdominal surgery, in the nineteenth century. Rate of incisional hernia after vertical midline incisions and transverse incisions are $2.9 \%$ and $3.6 \%$, respectively [1].

Etiologic factors associated with development of incisional hernia are; obesity, wound infection, advanced age, gender, pulmonary complications, jaundice, increased intra-abdominal pressure, pregnancy, emergency surgery, and malignancy. Many of these factors are related to poor wound healing and increased tension incision [2].

The most important etiological factor in development of incisional hernia is wound infection. Bucknall et al. investigated 1129 patients with abdominal surgeries, incisional hernia developed in $48 \%$ of patients who developed wound infection observed after the first surgery. Also in this study, $23 \%$ of the patients with incisional hernia developed wound infection, this rate was $4.5 \%$ in the clean wound [3].

The size of the fascial defect is also an etiologic factor of incisional hernia. Incisional hernias are classified as small $(<5 \mathrm{~cm})$, medium $(5-10 \mathrm{~cm})$ and large $(>10 \mathrm{~cm})$. The larger the hernia defect in the fascia, the higher the likelihood of incisional hernia development [4]. Incisional hernias cause a significant loss of manpower and morbidity, and adversely affect the quality of life. Surgery is the only treatment option, but it is not necessary to operate each of incisional hernias. Pain on hernia site, bad view, and intestinal obstruction are surgical indications [5].

Repairs can be made with either primary or mesh. Mesh should be used in hernias with high probability of relapse. Recurrence rate after primary repair is $37 \%$ and $15 \%$ with mesh repair [6].

We aimed to compare surgical methods of incisional hernias and discuss the postoperative data in this retrospective report.

\section{METHODS}

We retrospectively analyzed 54 patients whom operated because of a large incisional hernia between 2007 and 2011. We compared chronic diseases such as chronic obstructive pulmonary disease (COPD), diabetes mellitus, which causes the postoperative recurrence, etiologic factors such as age, gender, surgical techniques and relapse, the duration of postoperative drainage time, and hospital stay and development of postoperative seroma. 35 of 54 patients decolation larger than $5 \mathrm{~cm}$ were classified as group 1 and rest of 19 patients received decolation less than $5 \mathrm{~cm}$ were classified as group 2 .

Patients had been operated and after the middle for any reason, even large (10 $\mathrm{cm}$ or more) developed incisional hernia included in the study. The medical records retrospectively analyzed, whether it is associated with chronic disease have been identified. Causes of recurrence after incisional hernia operations are compared and obesity, diabetes mellitus, COPD, wound infection, seroma, age, gender, size and duration of hospital stay hernia constitute a risk for recurrence were statistically significant. All patents received $1 \mathrm{gr}$ of Cefazolin-Sodium preoperatively. We also performed post-operative follow-up, seroma, length of hospital stay, length of time, and their few to get the drain relapse analyzed. Decolation is defined as skin and subcutaneous flap area after repairment of incisional hernia. It is measured by a ruler pointed from the side of incisional hernia. Evaluation of the data was performed by "SPSS for Windows 15" software. Normal distribution of variables was determined using the KolmogorovSmirnov test. Normally distributed continuous variables, which show the mean \pm standard deviation, median not show a normal distribution $(25 \%-75 \%)$ in the form specified. Categorical variables were expressed as numbers and percentages. Student's t-test for continuous variables that show a normal distribution, normal distribution, the Mann-Whitney $\mathrm{U}$ test was used to not show. Categorical variables, Pearson's chi-square and Fisher's exact test was used for the evaluation. Analysis and $p<0.05$ was considered statistically significant.

\section{RESULTS}

Fourty-four were male (81.4\%), 10 (18.5\%) were female in study population. In this study, incisional hernia was more common in men. The mean age of patients was 47.9 (20-76). Mean age of men and women were 46.9 and 52.1 , respectively. Only 4 patients $(7.4 \%)$ were obese.

Medical records of patients with chronic diseases were examined. Four patients $(7.4 \%)$ had previously COPD, 4 patients $(7.4 \%)$ had diabetes. There was no significant difference between groups.

While 35 of the patients received decolation over $5 \mathrm{~cm}, 19$ patients received less than $5 \mathrm{~cm}$ decolation. Postoperative seroma rates of first 35 and second 19 patients were $3(8 \%), 2(10 \%)$ re- 
spectively. Only one of 5 patients with seroma developed recurrence $(p=0.81)$ (Table 1). Recurrence rates of the group 1 and 2 were one $(2 \%)$ and 7 $(36 \%)$ respectively. The difference was statistically significant $(p=0.001)$ (Table 2$)$. In terms of length of hospital stay, 29 patients (82\%) in group 1 and 14 patients $(73 \%)$ in group 2 were discharged within 7 days, respectively. The difference was not statistically significant $(p=0.497)$. Twenty-six $(74 \%)$ patients in group 1 and 12 (63\%) patients in group 2 received drainage catheter in first five days. Difference was no statistically significant difference $(p=$ 0.429 ). Table 2 shows association between hospitalization time and surgical procedure and Table 3 shows association between drainage time and surgical procedure.

Three of 35 and 1 of 19 patients had infection in group 1 and 2 respectively. Infection rate in both group was not statistically different $(p=0.56)$.

Table 1. Association between seroma development and surgical procedure and between recurrence and surgical procedure

\begin{tabular}{lccc}
\hline & \multicolumn{2}{c}{$\begin{array}{c}\text { Surgical procedure (Decolation } \\
\text { width over intact fascia) }\end{array}$} & $\mathrm{p}$ \\
\cline { 2 - 3 } & $>5 \mathrm{~cm}$ & $<5 \mathrm{~cm}$ & \\
\cline { 2 - 3 } Seroma development $(\mathrm{n})$ & 3 & 2 & 0.81 \\
Recurrence $(\mathrm{n})$ & 1 & 7 & 0.001 \\
\hline
\end{tabular}

Table 2. Association between hospitalization time and surgical procedure

Table 3. Association between drainage time and surgical procedure

\begin{tabular}{|c|c|c|c|c|c|c|c|c|c|c|c|c|c|c|}
\hline & & \multicolumn{13}{|c|}{ Hospitalization time (days) } \\
\hline & & 2 & 3 & 4 & 5 & 6 & 7 & 8 & 10 & 12 & 15 & 20 & 21 & Total \\
\hline \multirow{3}{*}{$\begin{array}{l}\text { Decolation width } \\
\text { over intact fascia }\end{array}$} & $>5 \mathrm{~cm}$ & 6 & 7 & 3 & 6 & 4 & 2 & 2 & 1 & 1 & 1 & 1 & 1 & 35 \\
\hline & $<5 \mathrm{~cm}$ & 1 & 3 & 4 & 5 & 1 & 0 & 2 & 3 & 0 & 0 & 0 & 0 & 19 \\
\hline & Total & 7 & 10 & 7 & 11 & 5 & 2 & 4 & 4 & 1 & 1 & 1 & 1 & 54 \\
\hline
\end{tabular}

\begin{tabular}{|c|c|c|c|c|c|c|c|c|c|c|c|c|c|c|}
\hline & & \multicolumn{12}{|c|}{ Drainage time (days) } & \multirow[b]{2}{*}{ Total } \\
\hline & & 2 & 3 & 4 & 5 & 6 & 7 & 8 & 9 & 10 & 11 & 12 & 15 & \\
\hline \multirow{3}{*}{$\begin{array}{l}\text { Decolation width } \\
\text { over intact fascia }\end{array}$} & $>5 \mathrm{~cm}$ & 10 & 5 & 6 & 5 & 1 & 3 & 1 & 0 & 2 & 1 & 1 & 0 & 35 \\
\hline & $<5 \mathrm{~cm}$ & 2 & 5 & 4 & 1 & 1 & 2 & 2 & 1 & 0 & 0 & 0 & 1 & 19 \\
\hline & Total & 12 & 10 & 10 & 6 & 2 & 5 & 3 & 1 & 2 & 1 & 1 & 1 & 54 \\
\hline
\end{tabular}

\section{DISCUSSION}

Incisional hernias are iatrogenic. Generally, they develop within a year after surgery. Recurrences are earlier after repair of an incisional hernia [7]. Incisional hernias cause incarceration, obstruction, strangulation, skin necrosis and perforation. The surgeon's experience and the choice of surgical procedure are very important in recurrence. There is no study in literature on how much space you will be placed grafts in large incisional hernias and how much dissection should be performed around the intact fascia. We observed the association between decolation of the width of the fascia with mesh spread and recurrence. Narrow fascia dissection (< $5 \mathrm{~cm}$ ) was found to be a closely related with the development of recurrence. Recurrence significantly reduce with over $5 \mathrm{~cm}$ wide decolations, while recurrence was high in fascia dissection under $5 \mathrm{~cm}$. The difference between the two surgical methods was statistically significant in terms of recurrence. Interestingly, this extensive dissection did not affect the rates of seroma development; drain commissioning time, length of hospital stay. There are different results about age in studies with incisional hernias $[8,9]$. In our study, the mean age was 47.9 years. There was no statistical difference between group 1 and 2 in terms of age.

Studies in literature are rumored incisional hernias to be seen more frequently in women than in men because of the weakness of the facial structure, hormonal influences, and the thickness of the subcutaneous fat tissue [8], we observed in our study men were more common than women 
$(81.4 \%)$. Most of the men in our study were active working farmers who could not rest enough long time after their first abdominal operation. This may increase intra-abdominal pressure and cause incisional hernias.

Many factors have been implicated in the formation of recurrence after incisional hernia repair. Existing co-morbidities should be taken into consideration in hernia repair. If preoperative evaluation is done well, it reduces postoperative complications. Treatment of patients with obesity and lung disease, the pathologies caused by the increase in intra-abdominal pressure (prostatism, constipation, etc.) therapy, concomitant diseases (diabetes mellitus, hypertension, etc.) should be brought under control. However, studies of COPD, concomitant diseases such as diabetes mellitus have shown no recurrence enhancing effect $[10,11]$. In our study, patients had concomitant diseases, 4 had diabetes mellitus $(7.4 \%)$, and 4 had COPD $(7.4 \%)$ but relapse was not associated with these diseases. Although the rate of postoperative complications in obesity significantly increases in the literature [11], in our study, only 4 patients developed incisional hernia was observed in obese $(7.4 \%)$ subjects.

In our study, factors that facilitate the existence of co-morbid diseases increase relapse and recurrence. Postoperatively, patients should be mobilized early, postural drainage should be provided, and there should be a good way to wound care.

In conclusion, the hernia sac, and at least $5 \mathrm{~cm}$ above the fascia around the decollation has primary importance in preventing relapse. When decolation of fascia with good postoperative wound care applied together on a large incisional hernia we believe postoperative complications, and therefore recurrence may significantly diminish. We suggest a more than $5 \mathrm{~cm}$ dissection in large incisional hernia repair. We also think that larger series are needed for standardization of the surgical procedure.

\section{REFERENCES}

1. Schoetz DJ, Jr., Coller JA, Veidenheimer MC. Closure of abdominal wounds with polydioxanone. A prospective study. Arch Surg 1988;123:72-74.

2. Sayar R, Bilgel H, Korun N, et al. İnsizyonel herni oluşumunda ve onarımında etkili faktörler. Ulusal Cerrahi Dergisi 1990;6:56-58.

3. Bucknall TE, Cox PJ, Ellis H. Burst Abdomen and Incisional Hernia - a Prospective-Study of 1129 Major Laparotomies. Brit Med J 1982;284:931-933.

4. Hesselink VJ, Luijendijk RW, Dewilt JHW, et al. An Evaluation of Risk-Factors in Incisional Hernia Recurrence. Surg Gynecol Obstet 1993;176:228-234.

5. Kingsnorth $A$. The management of incisional hernia. Annals of The Royal College of Surgeons of England. 2006;88:252.

6. de Vries Reilingh TS, van Geldere D, Langenhorst B, et al. Repair of large midline incisional hernias with polypropylene mesh: comparison of three operative techniques. Hernia 2004;8:56-59.

7. Skandalakis LJ GT, Mansberger AR, Mitchell WE, et al. Modern Hernia Repair: Embryological and Anatomical Basis of Surgery. New York: Parthenon; 1996.

8. Sauerland S, Schmedt CG, Lein S, et al. Primary incisional hernia repair with or without polypropylene mesh: a report on 384 patients with 5-year follow-up. Langenbeck Arch Surg 2005;390:408-412.

9. Vrijland W, Jeekel J, Steyerberg E, et al. Intraperitoneal polypropylene mesh repair of incisional hernia is not associated with enterocutaneous fistula. Brit J Surg 2000;87:348-352.

10. Bozdağ A, Nazlı O, Tansuğ T, et al. İnsizyonel Herniler. Cerrahi Tıp Arşivi 1998;3:104.1998;109.

11. Anthony T, Bergen PC, Kim LT, et al. Factors affecting recurrence following incisional herniorrhaphy. World $\mathrm{J}$ Surg 2000;24:95-101. 